\title{
Determination of Iron in Baby Weaning Food and Powder Milk
}

\section{Behrooz Jannat ${ }^{1}$, Naficeh Sadeghi1,2,3*, Mohammad Reza Oveisi², Masoomeh Behzad ${ }^{2}$, Mannan Hajimahmoodi², Farid Aghazadeh ${ }^{2}$}

\author{
${ }^{1}$ Halal Research Center, Ministry of Health and Medical Education, Tehran, Iran \\ ${ }^{2}$ Department of Drug and Food Control, School of Pharmacy, Tehran University of Medical Sciences, Tehran, Iran \\ ${ }^{3}$ Water Health Research Center, Ministry of Health and Medical Education, Tehran, Iran \\ Email: *nsadeghi@sina.tums.ac.ir
}

How to cite this paper: Jannat, B., Sadeghi, N., Oveisi, M.R., Behzad, M., Hajimahmoodi, M. and Aghazadeh, F. (2017) Determination of Iron in Baby Weaning Food and Powder Milk. Journal of Biosciences and Medicines, 5, 1-6.

https://doi.org/10.4236/jbm.2017.56001

Received: April 9, 2017

Accepted: June 24, 2017

Published: June 27, 2017

Copyright (c) 2017 by authors and Scientific Research Publishing Inc. This work is licensed under the Creative Commons Attribution International License (CC BY 4.0).

http://creativecommons.org/licenses/by/4.0/

\begin{abstract}
Infant formula provides the largest, if not sole, source of nutrition for an extended interval; the nutritional adequacy of the formula must be confirmed and the indications for its use were well understood. Both iron deficiency and iron excess during the fetal and neonatal period bode poorly for developing organ systems. Voltammetry is analytical method based on current potential measurements in electrochemical cells. In this study the concentration of iron in four brands of powder milk and baby food (based on rice and based on wheat) was analyzed with DPASV and voltammeter device. Total Means \pm SE of Iron in baby foods and powder milk $(\mathrm{n}=40)$ were $8.55 \pm 1.18 \mathrm{mg} / 100 \mathrm{~g}$, $5.21 \pm 0.66$ respectively. Iron level in baby food type I and II was lower than labeled value $(p<0.05)$. Concentration of Iron in powder milk type I and II was also lower than value of label $(p<0.05)$.
\end{abstract}

\section{Keywords}

Iron, Baby Weaning Food, Powder Milk, Voltammetry

\section{Introduction}

Iron is essential component of hemoglobin, an erythrocyte protein that transfers oxygen from the lungs to the tissues. Iron is necessary for growth, development, normal cellular functioning, and synthesis of some hormones and connective tissue [1]. Breast milk will give baby all the iron needed for the first 6 months. At around 6 months, baby will need iron-rich complementary foods as well as breast milk. Electrochemical methods are primarily preferred for trace analysis and speciation analysis, because of their high selectivity and very low detection limits, and because they do not require tedious extraction or pre concentration 
procedures [2]. As the redox character has an important role in most speciation analysis, electrochemical methods are especially used for speciation studies due to their significance in redox reactions. The technique of voltammetry to measure trace elements in pollen can be considered a good alternative for routine analysis, providing accuracy at lower costs [3]. The American Academy of Pediatrics is committed to the use of maternal breast milk as the ideal source of nutrition for infant feeding [4]. Apart from the breast milk, infant formula and baby weaning food have a special role in infant diet. Infants and young children are very susceptible to amount of trace element. DPASV is a benefit and applicable method for measurement of trace element in food products [5]. Determination of trace elements in food is of great importance, as some of them have nutritional significance, whilst others are toxic [6]. Long term exposure to low levels of toxic metals could be important, especially in relation to children. The developing central nervous system is no exception to this concept as both iron deficiency and iron overload present significant risks to the development and function of the young brain [7]. Detection techniques of trace metals generally have high costs to be used in routine analysis. However, differential pulse anodic stripping voltammetry (DPASV), has low operating costs and few structural requirements [2], besides having a scanning of "ppt" (parts per trillion) [8]. Human milk has the most suitable capability to meet infant and young children's necessities in the first six months of life [9]. After these ages, nutritional and psychological needs of infants are increased and breast milk isn't enough. So complementary or weaning food is recommended by WHO [10]. Weaning is passing from exclusive milk feeding to family food and is a very vulnerable period [11]. Infant and children are very susceptible and vulnerable to the whole amount of food's element, and their effects on health [12]. They have a low ability in excretion processes and immunity [13]. Differential pulse voltammetry has been widely used for trace element measurement in food samples. It makes possible to determine simultaneously several trace element and both thermodynamic and kinetic assays. ASV has been widely used for trace metal measurement in food samples this method is inexpensive selective and sensitive. In this study iron is determined in baby weaning food and powder milk available in Iran, by DPASV.

\section{Materials and Methods}

\subsection{Apparatus}

The voltammeter was Trace Analyzer model 746 instruments (Metrohm AG Ltd., Switzerland). The cell was a three-electrode system with an $\mathrm{Ag} / \mathrm{AgCl}$ electrode as reference electrode, a hanging mercury drop electrode (HMDE) as the working electrode and a platinum electrode as auxiliary electrode.

\subsection{Reagents and Solutions}

The nitric acid 65\%, Hydrochloric acid 37\%, Iron standard $1000 \mathrm{mg} \mathrm{Fe}$ (as chloride), Catechol $\left(\mathrm{C}_{6} \mathrm{H}_{4}(\mathrm{OH})_{2}\right), \mathrm{NaH}_{2} \mathrm{PO}_{4}, \mathrm{Na}_{2} \mathrm{HPO}_{4}$, Purified water, a number of 
40 samples of each baby food and formulas were prepared.

The phosphate buffer was $\mathrm{pH} 7.0$ containing $1.998 \mathrm{~g}$ Monosodium phosphates (sodium dihydrogen phosphate) and $2.1 \mathrm{~g}$ Disodium phosphate (sodium hydrogen phosphate) dissolved in $50 \mathrm{ml}$ Purified water. All glassware were soaked in Hydrochloric acid $37 \%$ for at least 7 days, washed three times with distilled deionized water, soaked in distilled deionized water and finally again soaked in Hydrochloric acid $37 \%$ until ready for use.

\subsection{Sample Preparation}

First, 2 grams of dry weight were added to $10 \mathrm{ml}$ of $65 \%$ nitric acid. Then put in the oven with a temperature of $450^{\circ} \mathrm{C}$ for 24 hours. Took samples digested with hydrochloric acid $0.2 \mathrm{M}$ in the volume of $25 \mathrm{ml}$. We added $10 \mathrm{ml}$ of phosphate buffer with $100 \mathrm{ml}$ of catechol. Next was stirred for 60 seconds at a speed of 2000 rpm. Nitrogen gas was continuously blown into the buffer drawing curves baseline. The electrodes used HMDE. Differential pulse anodic voltammetry technique was used. The applied voltage amplitude $50 \mathrm{mV}$ differential and had a time of $40 \mathrm{~ms}$ for each pulse. Flow was measured at $20 \mathrm{~ms}$, and the time of applying a voltage of 0.1 seconds. $-1000 \mathrm{mV}$ applied potential during the accumulation stage 90 seconds at a speed of $2000 \mathrm{rpm}$. $-1200 \mathrm{mV}$ to $-700 \mathrm{mV}$ applied voltage at $60 \mathrm{mV}$ per second. We added a $0.5 \mathrm{ml}$ of prepared sample. Measure and draw voltammogram was then added 3 times the standard iron. This process was repeated three times for each sample.

\subsection{Statistical Analysis}

Statistical analysis was performed using SPSS software version 19. The data are expressed as the mean \pm SD. The concentrations were calculated by the method of linear regression method. For the comparison of concentrations with the allowable value of standard or labels, one sample $t$ test was used. A $P$ value less than 0.05 were considered as significant.

\section{Results and Discussion}

Table 1 shows Iron content of the powder infant formula. Table 2 shows Iron content of two type of baby food.

Detection limits for Iron were $0.005 \mathrm{mg} / \mathrm{kg}, 0.005 \mathrm{mg} / \mathrm{kg}, 0.01 \mathrm{mg} / \mathrm{kg}$ and 0.05 $\mathrm{mg} / \mathrm{kg}$, respectively. Precision of the method expressed by relative standard deviation was 3.2 percent.

In 1981 the Codex Alimentarius infant formula standard set a requirement of a minimum iron content of $1 \mathrm{mg} / 100 \mathrm{kcal}$ [14]. Recent data indicate that lower iron contents can suffice to meet infant iron requirements. During the period when infant formula may be fed exclusively, i.e. before the introduction of complementary foods, infant formulae based on cows' milk protein supplying about $0.25 \mathrm{mg} / 100 \mathrm{kcal}$ and $0.6 \mathrm{mg} / 100 \mathrm{kcal}$ resulted in similar iron status and hematology results [15] while previous studies showed no difference for feeding infant formula with about $0.6 \mathrm{mg}$ and $1.0 \mathrm{mg} / 100 \mathrm{kcal}$, respectively [16]. Thus, there 
Table 1. Iron content in powder milk (mg/100g).

\begin{tabular}{ccccccc}
\hline & $\mathrm{N}$ & Mean $\pm \mathrm{SD}$ & Lower Bound & Upper Bound & Minimum & Maximum \\
\hline Hummana & 20 & $5.54 \pm 0.39$ & 5.35 & 5.72 & 4.96 & 6.29 \\
Biomil & 20 & $4.87 \pm 0.71$ & 4.54 & 5.21 & 4.07 & 6.65 \\
Total & 40 & $5.21 \pm 0.66$ & 4.99 & 5.42 & 4.07 & 6.65 \\
\hline
\end{tabular}

Table 2. Iron content in baby food (rice based and wheat based) (mg/100g).

\begin{tabular}{ccccccc}
\hline & $\mathrm{N}$ & Mean $\pm \mathrm{SD}$ & Lower Bound & Upper Bound & Minimum & Maximum \\
\hline Cerelac wheat & 20 & $8.41 \pm 1.00$ & 7.9390 & 8.8817 & 6.47 & 9.78 \\
Cerelac rice & 20 & $8.70 \pm 1.34$ & 8.0764 & 9.3340 & 6.62 & 11.00 \\
Total & 40 & $8.55 \pm 1.18$ & 8.1799 & 8.9356 & 6.47 & 11.00 \\
\hline
\end{tabular}

was no significant difference between infants fed formulae containing $0.25 \mathrm{mg}$, $0.6 \mathrm{mg}$ and $1.0 \mathrm{mg}$ per $100 \mathrm{kcal}$, and there were no infants with inadequate iron status in either group. The reliable determination of Iron by ASV is dependent on the $\mathrm{pH}$ of the solution. According to previous studies optimum $\mathrm{pH}$ was 7.0 and therefore determination of the elements was done in $\mathrm{pH} 7.5=0$. Iron and iron containing compounds play vital roles in cellular function in all organ systems. We found in this study that the concentrations of Iron were significantly lower than standard and labels value $(\mathrm{p}<0.05)$, respectively (Table 1$)$. Thus, the results indicated that more vigorous measures should be taken on the quality control of the similar products in the Iranian market. Haschke et al [17] reported a significantly lower copper balance in infants fed formula with a higher iron concentration $(10.2 \mathrm{mg} / \mathrm{L})$ than in infants fed formula with a lower iron concentration $(2.8 \mathrm{mg} \mathrm{Fe} / \mathrm{L})$. Saarinen et al found there was no correlation between iron absorption and hemoglobin, serum transferrin saturation or serum ferritin within the range of normal values [18]. Walter et al showed iron-fortified infant rice cereal can contribute substantially to preventing iron deficiency anemia [19]. Bradley et al reported milk-based formulas containing either 7.4 or 12.7 $\mathrm{mg} / \mathrm{L}$ iron support normal growth and iron status of healthy; term, normally fed infants during the first year and both are well tolerated [20]. Pisacane et al reported that none of the infants who were exclusively breast fed for 7 months or more and $43 \%$ of those who were breast fed for a shorter time were anemic and also infants who were exclusively breast fed for a prolonged period had a good iron status at 12 and 24 months [21]. In a study by Sadeghi et al. in Iran (2014) after analysis in four brands of baby food (rice and wheat based) and powder milk, the average of zinc and lead in baby food rice based, was higher than wheat based and levels of lead and cadmium in baby food wheat based, was higher formula, but were in standard limit [22].

\section{Conclusion}

The results of research showed that the amount of iron in the samples was less than the amount printed on cans that have milk and baby food. It seems to be 
more precise control of baby food for health and child development. A detailed technical report discusses iron requirements in infancy and the level of iron in breast milk and factors that affect this level. Attention also is given to: iron intake by breast-fed infants; recommendations for iron supplements; the distribution of iron in milk-binding factors; and the bioavailability of iron from breast milk. The coupling effect of iron and breast milk on immune status in infants is also discussed.

\section{Acknowledgements}

This work was student thesis and supported by grant (No: 92-02-33-19781), from Tehran University of Medical Sciences.

\section{References}

[1] Saracoglu, S., Saygi, K.O., Uluozlu, O.D., Tuzen, M. and Soylak, M. (2007) Determination of Trace Element Contents of Baby Foods from Turkey. Food Chemistry, 105, 280-285. https://doi.org/10.1016/j.foodchem.2006.11.022

[2] American Academy of Pediatrics. Committee on Nutrition (1998) Soy ProteinBased Formulas: Recommendations for Use in Infant Feeding. Pediatrics, 101.

[3] Shams, E., Abdollahi, H., Yekehtaz, M. and Hajian, R. (2004) H-Point Standard Addition Method in the Analysis by Differential Pulse Anodic Stripping Voltammetry, Simultaneous Determination of Lead and Tin. Talanta, 63, 359-364. https://doi.org/10.1016/j.talanta.2003.11.003

[4] Lozoff, B. and Georgieff, M.K. (2006) Iron Deficiency and Brain Development. Seminars in Pediatric Neurology, 13, 158-165.

https://doi.org/10.1016/j.spen.2006.08.004

[5] Somer, G. and Caliskan, C.A. (2009) New Method for the Simultaneous Determination of Fe (III), $\mathrm{Cu}$ (II), $\mathrm{Pb}$ (II), Zn (II), Cd (II), and Ni (II) in Wine Using Differential Pulse Polarography. Journal of Applied Electrochemistry, 39, 2027-2033. https://doi.org/10.1007/s10800-009-9915-1

[6] Spitzer, A.R. and Polin, R.A. (2001) Fetal and Neonatal Secrets (The Secrets Series). Hanley \& Belfus, Philadelphia.

[7] Ward, K.L., Tkac, I., Jing, Y., Felt, B., Beard, J., Connor, J., Schallert, T., Georgieff, M.K. and Rao, R. (2007) Gestational and Lactational Iron Deficiency Alters the Developing Striatal Metabolome and Associated Behaviors in Young Rats. Journal of Nutrition, 137, 1043-1049.

[8] SilveirA, T.A.D., Araujo, D.F.D., Marchini, L.C., Moreti, A.C.C.C. and Olinda, R. (2013) Detection of Metals by Differential Pulse Anodic Stripping Voltammetry (DPASV) in Pollen Collected from a Fragment of the Atlantic Forest in Piracicaba/SP. Ecotoxicology and Environmental Contamination, 8, 31-36. https://doi.org/10.5132/eec.2013.02.005

[9] Ryan, A.S. (1997) The Resurgence of Breastfeeding in the United States. Pediatrics, 99, E12. https://doi.org/10.1542/peds.99.4.e12

[10] WHO, UNICEF, UNFPA, UNAIDS (2004) HIV Transmission Through Breastfeeding: A Review of Available Evidence. World Health Organization, Geneva.

[11] Jannat, B., Sadeghi, N., Oveisi, M., Behfar, A.A., Komeilizadeh, H. and Shafaati, A. (2009) Simultaneous Determination of Lead, Cadmium, Copper and Zinc in Infant Formula by Anodic Stripping Voltammetery. Iranian Journal of Pharmaceutical 
Research, 8, 159-162.

[12] Scholl, T.O. (2005) Iron Status during Pregnancy: Setting the Stage for Mother and Infant. The American Journal of Clinical Nutrition, 81, 1218-1222.

[13] Steer, P.J. (2000) Maternal Hemoglobin Concentration and Birth Weight. The American Journal of Clinical Nutrition, 71, 1285-1287.

[14] Davidsson, L., Ziegler, E.E., Kastenmayer, P. and Hurrell, R.F. (2000) Erythrocyte Incorporationofiron by Infants: Iron Bioavailabilityfrom a Low-Iron Infant Formula and an Evaluation of the Usefulness of Correcting Erythrocyte Incorporation Values, Using a Reference Dose or Plasma Ferritin Concentrations. British Journal of Nutrition, 84, 845-853.

[15] Hernell, O. and Lönnerdal, B. (2002) Iron Status of Infants Fed Low-Iron Formula: No Effect of Added Bovine Lactoferrin or Nucleotides. Journal of Clinical Nutrition, 76, 858-864.

[16] Walter, T., Pino, P., Pizarro, F. and Lozoff, B. (1998) Prevention of Iron-Deficiency Anemia: Comparison of High- and Low-Iron Formulas in Term Healthy Infants after Six Months of Life. Journal of Pediatrics, 132, 635-640. https://doi.org/10.1016/S0022-3476(98)70352-X

[17] Haschke, F., Ziegler, E.E., Edwards, B.B. and Fomon, S.J. (1986) Effect of Iron Fortification of Infant Formula on Trace Mineral Absorption. Journal of Pediatric Gastroenterology and Nutrition, 5, 768-773.

https://doi.org/10.1097/00005176-198609000-00018

[18] Saarinen, U.M. and Siimes, M.A. (1977) Iron Absorption from Infant Milk Formula and the Optimal Level of Iron Supplementation. Acta Paediatrica Scandinavica, 66, 719-722. https://doi.org/10.1111/j.1651-2227.1977.tb07978.x

[19] Walter, T., Dallman, P.R., Pizarro, F., Velozo, L., Peña, G., Bartholmey, S.J., Hertrampf, E., Olivares, M., Letelier, A. and Arredondo, M. (1993) Effectiveness of Iron-Fortified Infant Cereal in Prevention of Iron Deficiency Anemia. Pediatrics, 91, 976-982.

[20] Bradley, C.K., Hillman, L., Sherman, A.R., Leedy, D. and Cordano, A. (1993) Evaluation of Two Iron Fortified, Milk Based Formulas during Infancy. Pediatrics, 91, 908-914.

[21] Pisacane, A., Vizia, B.D., Valiante, A., Vaccaro, F., Russo, M., Grillo, G. and Giustardi, A. (1995) Iron Status in Breast-Fed Infants. Journal of Pediatrics, 127, 429-431. https://doi.org/10.1016/S0022-3476(95)70076-5

[22] Sadeghi,N., Oveisi, M.R., Jannat, B., Hajimahmoodi, M., Behfar, A., Behzad, M., Norouzi, N., Oveisi, M. and Jannat, B. (2014) Simultaneous Measurement of Zinc, Copper, Lead and Cadmium in Baby Weaning Food and Powder Milk by DPASV. Iranian Journal of Pharmaceutical Research, 13, 345-349. 
Submit or recommend next manuscript to SCIRP and we will provide best service for you:

Accepting pre-submission inquiries through Email, Facebook, LinkedIn, Twitter, etc. A wide selection of journals (inclusive of 9 subjects, more than 200 journals)

Providing 24-hour high-quality service

User-friendly online submission system

Fair and swift peer-review system

Efficient typesetting and proofreading procedure

Display of the result of downloads and visits, as well as the number of cited articles Maximum dissemination of your research work

Submit your manuscript at: http://papersubmission.scirp.org/

Or contact jbm@scirp.org 